\title{
The Characteristics of Innovative Teachers: The Relationship between Science Teachers' Views on Student Achievement and Learning and Teaching Motivation
}

\author{
Kamil Arif Kirkiç ${ }^{1}$, Ömer Yahşi²* \\ ${ }^{1}$ Department of Educational Sciences, Faculty of Education, İstanbul Sabahattin Zaim University, İstanbul, Turkey, ${ }^{2}$ Provincial Directorate of National \\ Education, İzmir, Turkey
}

*Corresponding Author: oyahsi@gmail.com

\section{ABSTRACT}

Determining teachers' views on student success and learning are considered important in terms of increasing the level of students' learning. The motivation people have can affect their attitude toward their job. This becomes even more important in teachers who have a significant impact on an individual's life. It is, therefore, seen as important to determine teachers' teaching motivation. The aim of this study was to determine the relationship between secondary school science teachers' views on student achievement and learning and their own level of teaching motivation. This research used the correlational survey method, a method in quantitative research. The sample group consisted of teachers (124 female and 39 male science teachers) working in Izmir. Two data collection tools were used in the study: The "Teacher Motivation Scale" and the "Teachers" Opinions Scale about Student Achievement and Learning. Participants' demographic information was obtained using a "Personal Information Form" designed by the researchers. According to the results of the study, there was no difference according to gender variable but there was a significant difference in favor of science teachers who had a bachelor's degree between the groups. The study showed that as the age and teachers' years of service increased, their views on student achievement and learning become more negative. According to the results, it is recommended to organize well-planned inservice training to increase the teaching motivation and conduct in-depth research to understand the relationship among teacher beliefs, practice, and school context.

KEY WORDS: innovative teaching; teaching beliefs; teaching motivation; student achievement; science teachers; science education

\section{INTRODUCTION}

○

Teachers play a crucial role in changing schools and classrooms. It is recognized that teachers' beliefs and ideas, which are the essential components of the learning-teaching process, shape their behavior in the learning environment (Alam and Farid, 2011; Bardak and Karamustafaoğlu, 2016; Gök and Kabasakal, 2019). When the teaching process is organized according to the students' need to improve their achievement and learning, the opinions of the teachers who organize the teaching are considered very important. According to Chai and Khine (2008), teachers' ideas about learning and teaching reflect their pedagogic beliefs and fall into two categories: Knowledge transfer and knowledge construction. Teachers whose pedagogic beliefs fallen into the knowledge transfer category, that is, beliefs that are teacher centered and subject oriented, adopt didactic teaching practices. Those whose beliefs fall into the knowledge construction category, that is, beliefs that are student centered and learning oriented, adopt constructivist teaching practices (Chai and Khine, 2008). The classroom is a complex culture (Geertz, 1973; Lieberman, 1992) in which teachers and students discover, discuss, and collect personal knowledge, beliefs, and interpretations of their environment through continuous epistemological processes (von Glasersfeld, 1987).

Johnson (2012) states that teachers subconsciously reflect their ideas about learning and teaching in the classroom environment when they step into the classroom as a teacher. Therefore, teachers interpret innovations and changes concerning their beliefs and their practices and react to these changes in parallel with their beliefs (Kuzborska, 2011). It should also be kept in mind that teachers' beliefs are an essential predictor of behavior (Pajares, 1992). Teacher beliefs are considered cognitive structures that show how teachers interpret and apply instruction in the classroom and how they progress student learning and success (Skott, 2015).

The teaching components effective in student achievement and learning level are the tips, reinforcement, and participation used by the teacher while teaching. The feedback-corrective cycle is also a crucial component of instruction that significantly impacts students' success and learning (Bloom, 1971; Y1ldıran, 2006). Teachers' beliefs about learning are vital in terms of student learning processes and products as they form the foundations of learning in young people's extended school life and help them adopt lifelong learning abilities (Borg, 2001). 
For more than 60 years, research has been conducted on teacher beliefs (Fives and Buehl, 2012). Many science education studies have focused on science teachers' epistemological beliefs (Gallagher, 1991; Hodson, 1985; King, 1991; Luft and Roehrig, 2007; Nadeau and Desautels, 1984; Prawat, 1992). According to a study conducted by Hashweh (1991), while constructivist teachers emphasized the active role of the learner, learning empiricists emphasized the role of the external reinforcement in learning. Etchberger and Shaw (1992) examined science teachers' beliefs about teaching and learning and how they influenced their teaching methods. There is a study on primary school teachers' beliefs and views about science teaching and learning (Levitt, 2002) and the relationship between science teachers' beliefs and practices (Mansour, 2009). There are also studies focusing on science and mathematics teachers' selfefficacy, thinking styles, and similar teachers' characteristics (Anderson and Mitchener, 1994; Bullough, 1989; Clark and Peterson, 1986; Trumball, 1991).

One of the primary purposes of teachers while performing their profession should be to ensure students learn at the highest level. The approach teachers adopt and the set of values, methods, and techniques they use in learning environments in accordance with this approach are related to teachers' beliefs about learning (Borko and Putnam, 1996; Demir and Akınoğlu, 2010; Demir, 2013; Ediger, 2000; Hashweh, 1996). Studies have shown that teachers' expectations of students directly relate to their students' achievement levels (Gales and Yan, 2001; Love, 2002; Muijs and Reynolds, 2002; Rashidi and Mughadam, 2014). Studies reveal an important relationship between teacher beliefs and how teachers behave in the teaching process (Abu Radwan, 2019; Beck et al., 2000; Levitt, 2002; Liu, 2003; Turan, 2019).

According to Mansour (2009), some teachers believe in teaching students through lecturing or direct instruction, while others reflect constructivist views of teaching and learning using collaborative learning or research. He states that most science teachers tend to mix science teaching methods. Dewey (1938) points out that personal experience is a fundamental source of education. In other words, it is possible to say that teachers' experience as individuals in society plays a critical role in shaping their beliefs about teaching and learning. Therefore, teachers' motivation to teach is an important issue. There are various definitions of motivation, which is one of the main factors increasing people's will to live and make themselves more successful in social life. Motivation is a dynamic state of arousal that initiates, directs, coordinates, strengthens, terminates, and evaluates cognitive and motor processes by selecting, sequencing, and taking action in the first wishes and desires (Dörnyei and Ushioda, 2011). It is known that motivation is fundamental to individuals' achievement during the teaching-learning process (Kaya, 2001; Lin et al., 2003). In the literature, there are many studies on motivation and its positive effects on learning (Akioka and Gilmore, 2013; Fernet et al., 2012; Glynn et al., 2005; Martin, 2013; Öztürk and Dündar, 2003; Vallerand et al., 1997). A study by Karadağ et al. (2010) revealed that there were potential variables between perceptions of manager supervision and the level of work motivation for teachers.

The aim of this current study was to determine the relationship between science teachers' views on student achievement and learning and their own teaching motivation. Determining teachers' views on student achievement and learning are considered necessary to increase the level of student learning. The motivation people have can change their attitude toward their job. This issue becomes even more important for teachers, who have a significant impact on an individual's life. It is, therefore, important to determine teachers' teaching motivation. Accordingly, this study considered the following questions:

- What are secondary school science teachers' views on student achievement and learning and their level of teaching motivation?

- What are the secondary school science teachers' opinions about student achievement and learning and their teaching motivation according to gender?

- What are the secondary school science teachers' opinions on student achievement and learning and their teaching motivation according to their educational level?

- What is the relationship between secondary school science teachers' views on student achievement and learning, their teaching motivation levels, and the teacher's age and years of service?

- Do age and years of service of secondary school science teachers predict their opinions about student achievement and learning and teaching motivation?

\section{METHODOLOGY}

\section{Method}

This research used the correlational survey method, a method in quantitative research. Survey models are studies that aim to collect data to determine the particular characteristics of a group (Büyüköztürk, 2012). Karasar (2014) states that the correlational survey method aims to reveal the relationship between two variables. In this study, the survey method was used to determine the relationship between science teachers' views on student achievement and learning and teaching motivation. The participants were selected by random cluster sampling (Büyüköztürk, 2018).

\section{Participants}

The research participants were science teachers working in Izmir in the 2020-2021 academic year. The study's sample group, which was determined by random cluster sampling, consisted of teachers working in different branches in Izmir.

The distribution of demographic characteristics of the science teachers included in the sampling is presented in Table 1.

Table 1 shows the demographic characteristics of the participants, which are as follows: By gender, $76.1 \%(f=124)$ were female science teachers and $23.9 \%(f=39)$ were male 
science teachers. By educational level, 87.7\% $(f=143)$ had a bachelor's degree and $12.3 \%(\mathrm{f}=20)$ had a postgraduate degree.

\section{Data Collection Tools}

Two data collection tools were used in the study. The "Teacher Motivation Scale" (TMS) which was developed by Kauffman et al. (2011) and adapted to Turkish by Güzel Candan and Evin Gencel (2015) and the "Teachers' Opinions Scale about Student Achievement and Learning Scale" (TOS-ASAL) developed by Kırkıç et al. (2020) were implemented. In addition, participants' demographic information was obtained using the "Personal Information Form" designed by the researchers.

The TMS has two dimensions: Intrinsic motivation and extrinsic motivation. Consisting of 12 items, this is a 6-point Likert type ranging from 1 (strongly disagree) to 6 (strongly agree). The minimum score that can be obtained is 12 , while the maximum is 72 .

TOS-ASAL consists of 11 items. The scale has four dimensions: Opinion on the Relationship between Students' Emotional Characteristics and Achievement (TOS-ASAL F1), Opinion on the Relationship between Student Pre-Learning and Achievement (TOS-ASAL F2), Opinion on the Relationship between Intelligence (TOS-ASAL F3) and Achievement, and Opinion on the Changeability of Student Achievement (TOSASAL F4). The first five items are reverse scored. The high scores of the scale show that the teachers' opinions on student achievement and learning are positive.

\section{Analysis of Data and Findings}

The findings of the data obtained are presented below. Skewness and kurtosis values were checked to determine whether the data showed normal distribution and these values are presented in Table 2 .

\begin{tabular}{|c|c|c|c|}
\hline \multicolumn{4}{|c|}{$\begin{array}{l}\text { Table 1: Demographic characteristics of educators } \\
\text { participating in the study }\end{array}$} \\
\hline \multicolumn{2}{|c|}{ Demographic characteristics } & \multirow{2}{*}{$\frac{\text { Frequency }}{124}$} & \multirow{2}{*}{$\frac{\text { Percentage }}{76.1}$} \\
\hline Gender & Female & & \\
\hline & Male & 39 & 23.9 \\
\hline \multirow[t]{2}{*}{ Educational level } & Bachelor's & 143 & 87.7 \\
\hline & Postgraduate & 20 & 12.3 \\
\hline Total & & 163 & 100.0 \\
\hline
\end{tabular}

As shown in Table 2, kurtosis and skewness values were in the range of \pm 1.5 according to the results of the normality test conducted to determine the sub-dimensions of the sample group's TOS-ASAL and total scale scores and total scores of TMS. According to Tabachnick and Fidell (2013), skewness and kurtosis values in the range of \pm 1.5 are acceptable for normality. The scores obtained from the scales were considered to be normally distributed and the data were analyzed parametrically using the SPSS program.

The results of the analysis for the first study question "What are secondary school science teachers' views on student success and learning and their level of teaching motivation?" are presented in Table 3 .

In Table 3, teachers' average scores obtained from the scales are as follows:

TOS-ASAL F1 sub-dimension $(\bar{x}=14.30)$, TOS-ASAL F2 sub-dimension $(\bar{x}=6.57)$, TOS-ASAL F3 sub-dimension $(\bar{x}=11.20)$, TOS-ASAL F4 sub-dimension $(\bar{x}=7.71)$, TOSASAL total score $(\bar{x}=39.78)$, TMS internal sub-dimension $(\bar{x}=27.04)$, TMS external sub-dimension $(\bar{x}=14.76)$, and TMS total score $(\bar{x}=41.80)$. The findings suggest that science teachers' TOS-ASAL total scores and sub-dimension scores were at the medium level; TMS total scores and subdimensions were just above the medium level.

Results for the second question of the study "What are the secondary school science teachers' opinions about student achievement and learning and their teaching motivation according to gender?" are presented in Table 4 . An independent group t-test was conducted regarding the question.

As shown in Table 4, the difference between the groups in terms of TOS-ASALF4 $\left.\left[\mathrm{t}_{161}\right)=2.170 ; \rho<0.05\right]$ was in favor of male science teachers, TMS internal $\left[\mathrm{t}\left({ }_{161}\right)=\right.$ $2.170 ; \rho<0.05]$ was in favor of female science teachers, and TMS total $\left[\mathrm{t}\left({ }_{161}\right)=2.286 ; \rho<0.05\right]$ was in favor of female science teachers. However, there was no difference according to gender in terms of other variables.

The third study question was "What are the secondary school science teachers" opinions on student achievement and learning and their teaching motivation according to their educational level?" An independent group t-test was conducted; the results are presented in Table 5.

\begin{tabular}{|c|c|c|c|c|c|c|c|c|c|}
\hline \multirow[t]{2}{*}{ Dimensions } & \multirow[t]{2}{*}{$\mathbf{n}$} & \multirow[t]{2}{*}{ Min } & \multirow[t]{2}{*}{ Max } & \multirow[t]{2}{*}{ Mean } & \multirow[t]{2}{*}{ SD } & \multicolumn{2}{|c|}{ Skewness } & \multicolumn{2}{|c|}{ Kurtosis } \\
\hline & & & & & & Statistic & SEM & Statistic & SEM \\
\hline TOS-ASAL F1 & 163 & 6 & 20 & 14.30 & 2.915 & -0.161 & 0.190 & -0.208 & 0.378 \\
\hline TOS-ASAL F2 & 163 & 2 & 10 & 6.57 & 1.663 & 0.046 & 0.190 & -0.081 & 0.378 \\
\hline TOS-ASAL F3 & 163 & 5 & 15 & 11.20 & 2.359 & -0.301 & 0.190 & -0.264 & 0.378 \\
\hline TOS-ASAL F4 & 163 & 2 & 10 & 7.71 & 1.818 & -0.661 & 0.190 & 0.154 & 0.378 \\
\hline TOS-ASAL total & 163 & 22 & 50 & 39.78 & 4.581 & -0.292 & 0.190 & 0.816 & 0.378 \\
\hline TMS & 163 & 7 & 42 & 27.04 & 7.272 & -0.368 & 0.190 & -0.240 & 0.378 \\
\hline TMS & 163 & 5 & 30 & 14.76 & 4.574 & 0.666 & 0.190 & 0.853 & 0.378 \\
\hline TMS total & 163 & 14 & 72 & 41.80 & 10.664 & 0.012 & 0.190 & 0.176 & 0.378 \\
\hline
\end{tabular}


As shown in Table 5, there was a significant difference in favor of science teachers who had a bachelor's degree in terms of TOS-ASALF1 F1 [ $\left.\left.\mathrm{t}_{161}\right)=2.584 ; \rho<0.05\right]$.

Pearson correlational analysis was conducted regarding the fourth study question "Is there a significant relationship between secondary school science teachers' views on student achievement and learning and their teaching motivation levels and the teachers' age and years of service?" The results are presented in Tables 6 and 7.

According to the values in Table 6, there was a low-level statistically significant relationship between the TOS-ASAL F2 and age $(r=-0.243 ; \rho<0.01)$ and years of service $(\mathrm{r}=-0.280 ; \rho<0.01)$.

It was determined that there was a low-level negative relationship between the TOS-ASAL F3 and age $(\mathrm{r}=-0.215$; $\rho<0.01)$ and years of service $(r=-0.190 ; \rho<0.01)$. There was a low-level statistically negative meaningful relationship between the TOS-ASAL F4 and age $(r=-0.227 ; \rho<0.01)$

\begin{tabular}{|c|c|c|c|c|}
\hline Dimensions & n & Mean & SD & SEM \\
\hline TOS-ASAL F1 & 163 & 14.30 & 2.915 & 0.228 \\
\hline TOS-ASAL F2 & 163 & 6.57 & 1.663 & 0.130 \\
\hline TOS-ASAL F3 & 163 & 11.20 & 2.359 & 0.185 \\
\hline TOS-ASAL F4 & 163 & 7.71 & 1.818 & 0.142 \\
\hline TOS-ASAL total & 163 & 39.78 & 4.581 & 0.359 \\
\hline TMS internal & 163 & 27.04 & 7.272 & 0.570 \\
\hline TMS external & 163 & 14.76 & 4.574 & 0.358 \\
\hline TMS total & 163 & 41.80 & 10.664 & 0.835 \\
\hline
\end{tabular}

and years of service $(r=-0.227 ; \rho<0.01)$. There was a medium-level statistically negative relationship between the TOS-ASAL total and age $(\mathrm{r}=-0.334 ; \rho<0.01)$ and years of service $(r=-0.340 ; \rho<0.01)$.

According to the values in Table 7, there was a low-level positive meaningful relationship between the Teachers' Opinions Scale about Student Achievement and Learning sub-dimension TOS-ASAL F1 and TMS internal $(r=0.155$; $\rho<0.01)$ and TMS $(r=0.241 ; \rho<0.01)$. It was determined that there was a medium level positive relationship between the TOS-ASAL F1 and TMS external $(r=0.316 ; \rho<0.01)$. There was a low-level positive meaningful relationship between the Teachers' Opinions Scale about Student Achievement and Learning sub-dimension TOS-ASAL F2 and TMS external $(\mathrm{r}=0.159 ; \rho<0.01)$ and TMS $(\mathrm{r}=0.173 ; \rho<0.01)$.

There was a low-level negative relationship between the sub-dimension TOS-ASAL F3 and TMS internal $(\mathrm{r}=-0.172$; $\rho<0.01)$, TMS external $(\mathrm{r}=-0.271 ; \rho<0.01)$, and TMS total $(\mathrm{r}=-0.233 ; \rho<0.01)$.

The fifth question of the study was "Do age or years of service of secondary school science teachers predict their opinions about student achievement and learning and teaching motivation? The data were analyzed with regression analysis and are presented in Table 8.

As shown in Table 8, age level predicted TOS-ASAL F2 $\left(\mathrm{R}^{2}=0.059 ; \rho<0.01\right)$ and years of service predicted the TOS-ASAL F2 sub-dimension $\left(\mathrm{R}^{2}=0.078 ; \rho<0.01\right)$. Age level explained $5.9 \%$ of the total variance in TOS-ASAL F2 and years of service predicted $7.8 \%$ of the total variance TOSASAL F2 level of teachers.

Age level predicts the TOS-ASAL F3 sub-dimension $\left(R^{2}=0.046 ; \rho<0.01\right)$ and years of service predicted the TOS-

\begin{tabular}{|c|c|c|c|c|c|c|c|c|}
\hline \multirow[t]{2}{*}{ Dimensions } & \multirow[t]{2}{*}{ Groups } & \multirow[t]{2}{*}{$\mathbf{N}$} & \multirow[t]{2}{*}{ Mean } & \multirow[t]{2}{*}{ SD } & \multirow[t]{2}{*}{ SEM } & \multicolumn{3}{|c|}{ t-test } \\
\hline & & & & & & $t$ & df & $\rho$ \\
\hline \multirow[t]{2}{*}{ TOS-ASALF1 } & Male & 39 & 14.23 & 3.280 & 0.525 & -0.171 & 161 & 0.864 \\
\hline & Female & 124 & 14.32 & 2.804 & 0.252 & & & \\
\hline \multirow[t]{2}{*}{ TOS-ASALF2 } & Male & 39 & 6.03 & 1.857 & 0.297 & -2.380 & 161 & 0.018 \\
\hline & Female & 124 & 6.74 & 1.566 & 0.141 & & & \\
\hline \multirow[t]{2}{*}{ TOS-ASALF3 } & Male & 39 & 11.15 & 2.540 & 0.407 & -0.129 & 161 & 0.898 \\
\hline & Female & 124 & 11.21 & 2.310 & 0.207 & & & \\
\hline \multirow[t]{2}{*}{ TOS-ASALF4 } & Male & 39 & 8.26 & 1.943 & 0.311 & 2.170 & 161 & 0.031 \\
\hline & Female & 124 & 7.54 & 1.750 & 0.157 & & & \\
\hline \multirow[t]{2}{*}{ TOS-ASAL total } & Male & 39 & 39.67 & 3.841 & 0.615 & -0.175 & 161 & 0.861 \\
\hline & Female & 124 & 39.81 & 4.804 & 0.431 & & & \\
\hline \multirow[t]{2}{*}{ TMS internal } & Male & 39 & 24.54 & 7.830 & 1.254 & -2.499 & 161 & 0.013 \\
\hline & Female & 124 & 27.82 & 6.936 & 0.623 & & & \\
\hline \multirow[t]{2}{*}{ TMS external } & Male & 39 & 13.90 & 5.077 & 0.813 & -1.355 & 161 & 0.177 \\
\hline & Female & 124 & 15.03 & 4.391 & 0.394 & & & \\
\hline \multirow[t]{2}{*}{ TMS total } & Male & 39 & 38.44 & 11.589 & 1.856 & -2.286 & 161 & 0.024 \\
\hline & Female & 124 & 42.85 & 10.178 & 0.914 & & & \\
\hline
\end{tabular}




\begin{tabular}{|c|c|c|c|c|c|c|c|c|}
\hline \multirow[t]{2}{*}{ Dimensions } & \multirow[t]{2}{*}{ Groups } & \multirow[t]{2}{*}{ n } & \multirow[t]{2}{*}{ Mean } & \multirow[t]{2}{*}{ SD } & \multirow[t]{2}{*}{ SEM } & \multicolumn{3}{|c|}{ t-test } \\
\hline & & & & & & $t$ & df & $\rho$ \\
\hline \multirow[t]{2}{*}{ TOS-ASALF1 } & Bachelor's & 143 & 14.52 & 2.938 & 0.246 & 2.584 & 161 & .011 \\
\hline & Postgraduate & 20 & 12.75 & 2.245 & 0.502 & & & \\
\hline \multirow[t]{2}{*}{ TOS-ASALF2 } & Bachelor's & 143 & 6.50 & 1.635 & 0.137 & -1.381 & 161 & .169 \\
\hline & Postgraduate & 20 & 7.05 & 1.820 & 0.407 & & & \\
\hline \multirow[t]{2}{*}{ TOS-ASALF3 } & Bachelor's & 143 & 11.15 & 2.388 & 0.200 & -.715 & 161 & .476 \\
\hline & Postgraduate & 20 & 11.55 & 2.164 & 0.484 & & & \\
\hline \multirow[t]{2}{*}{ TOS-ASALF4 } & Bachelor's & 143 & 7.71 & 1.846 & 0.154 & -.100 & 161 & .920 \\
\hline & Postgraduate & 20 & 7.75 & 1.650 & 0.369 & & & \\
\hline \multirow[t]{2}{*}{ TOS-ASAL total } & Bachelor's & 143 & 39.87 & 4.455 & 0.373 & .707 & 161 & .481 \\
\hline & Postgraduate & 20 & 39.10 & 5.486 & 1.227 & & & \\
\hline \multirow[t]{2}{*}{ TMS internal } & Bachelor's & 143 & 27.15 & 7.369 & 0.616 & .515 & 161 & .607 \\
\hline & Postgraduate & 20 & 26.25 & 6.656 & 1.488 & & & \\
\hline \multirow[t]{2}{*}{ TMS external } & Bachelor's & 143 & 14.80 & 4.577 & 0.383 & .323 & 161 & .747 \\
\hline & Postgraduate & 20 & 14.45 & 4.662 & 1.042 & & & \\
\hline \multirow[t]{2}{*}{ TMS total } & Bachelor's & 143 & 41.95 & 10.696 & 0.894 & .490 & 161 & .625 \\
\hline & Postgraduate & 20 & 40.70 & 10.643 & 2.380 & & & \\
\hline
\end{tabular}

Table 6: Results of Pearson product-moment correlational analysis performed to determine secondary school science teachers' views on student achievement and learning and their teaching motivation in terms of age and years of service

\begin{tabular}{lccc}
\hline Variables & $\mathbf{n}$ & Age & Years of service \\
\hline TOS-ASALF1 & 163 & -0.070 & -0.120 \\
TOS-ASALF2 & 163 & $-0.243^{* *}$ & $-0.280^{* *}$ \\
TOS-ASALF3 & 163 & $-0.215^{* *}$ & $-0.190^{*}$ \\
TOS-ASAL F4 & 163 & $-0.227^{* *}$ & $-0.163^{*}$ \\
TOS-ASAL & 163 & $-0.334^{* *}$ & $-0.340^{* *}$ \\
TMS internal & 163 & 0.062 & 0.010 \\
TMS external & 163 & 0.006 & -0.051 \\
TMS & 163 & 0.045 & -0.015 \\
\hline
\end{tabular}

**Correlation is significant at the 0.01 level, *correlation is significant at the 0.05 level

Table 7: Results of Pearson product-moment correlation analysis performed to determine the relationship between the scores obtained from the teachers' opinions scale about student achievement and learning and teaching motivation scale

\begin{tabular}{lcccc}
\hline Variables & $\mathbf{n}$ & TMS internal & TMS external & TMS \\
\hline TOS-ASAL F1 & 163 & $0.155^{*}$ & $0.316^{* *}$ & $0.241^{* *}$ \\
TOS-ASAL F2 & 163 & 0.153 & $0.159^{*}$ & $0.173^{*}$ \\
TOS ASAL F3 & 163 & $-0.172^{*}$ & $-0.271^{* *}$ & $-0.233^{* *}$ \\
TOS ASAL F4 & 163 & -0.073 & $-0.209^{* *}$ & -0.139 \\
TOS ASAL & 163 & 0.037 & 0.037 & 0.041 \\
\hline
\end{tabular}

**Correlation is significant at the 0.01 level, *correlation is significant at the 0.05 level

ASAL F3 sub-dimension $\left(\mathrm{R}^{2}=0.036 ; \rho<0.05\right)$ meaningfully. Age level predicted $4.6 \%$ of the total variance in the TOS-
ASAL F3 level of the teachers, and years of service predicted $3.6 \%$ of the total variance in TOS-ASAL F3 level of teachers.

The TOS-ASAL F4 sub-dimension was predicted by age level $\left(\mathrm{R}^{2}=0.051 ; \rho<0.01\right)$ and years of service level $\left(\mathrm{R}^{2}=0.026 ; \rho<0.05\right)$ meaningfully. The age level explained $5.1 \%$ of the total variance in the TOS-ASAL F4 level of teachers and years of service explained $2.6 \%$ of the total variance in the TOS-ASAL F4 level of teachers.

Analysis showed that age level $\left(\mathrm{R}^{2}=0.111 ; \rho<0.01\right)$ and years of service $\left(R^{2}=0.116 ; \rho<0.01\right)$ predicted TOS ASAL total scores meaningfully. Age level explained $11.1 \%$ of the total variance in the TOS-ASAL total level of the teachers and years of service explained $11.6 \%$ of the total variance in the TOS-ASAL total level of teachers.

According to the analysis, TOS ASALF1 predicted TMS external $\left(\mathrm{R}^{2}=0.10 ; \rho<0.01\right)$, TOS-ASAL F2 predicted TMS external sub-dimension $\left(\mathrm{R}^{2}=0.025 ; \rho<0.05\right)$, TOS-ASAL F3 predicted TMS external sub-dimension $\left(\mathrm{R}^{2}=0.073 ; \rho<0.01\right)$, and TOSASAL F4 predicted TMS external sub-dimension $\left(\mathrm{R}^{2}=0.044\right.$; $\rho<0.01$ ) meaningfully. TOS-ASAL F1 level explained $10.0 \%$ of the total variance in TMS external level of teachers, TOS-ASAL F2 explained $2.5 \%$ of the total variance in TMS external level of teachers, TOS-ASAL F3 explained $7.3 \%$ of the total variance in TMS external level of teachers, and TOS-ASAL F4 explained $4.4 \%$ of the total variance in the TMS external level of teachers.

The results showed that TOS-ASAL F1 level predicted the TMS TOTAL dimension $\left(\mathrm{R}^{2}=0.58 ; \rho<0.01\right)$ and TOS-ASAL F2 level predicted the TMS total dimension $\left(\mathrm{R}^{2}=0.030\right.$; $\rho<0.05$ ) meaningfully. TOS-ASAL F1 level explained 5.8\% of the total variance in TMS total level of teachers and TOS ASAL F2 level explained 3.0\% of the total variance in the TMS total level of teachers. 


\begin{tabular}{|c|c|c|c|c|c|c|c|c|c|c|}
\hline Independent variable & Dependent variable & B & SE & $(\beta)$ & $\mathbf{T}$ & $\mathbf{P}$ & $\mathbf{R}$ & $\mathbf{R}^{2}$ & $\mathbf{F}$ & $\rho$ \\
\hline Constant & TOS-ASAL F2 & 8.654 & 0.666 & -0.243 & 12.988 & 0.000 & 0.243 & 0.059 & 10.144 & 0.002 \\
\hline Age & & -0.050 & 0.016 & & -3.185 & 0.002 & & & & \\
\hline Constant & TOS-ASAL F2 & 7.546 & 0.292 & -0.280 & 25.822 & 0.000 & -0.280 & 0.078 & 13.650 & 0.000 \\
\hline Years of service & & -0.056 & 0.015 & & -3.695 & 0.000 & & & & \\
\hline Constant & TOS-ASAL F3 & 13.804 & 0.952 & -0.215 & 14.501 & 0.000 & 0.215 & 0.046 & 7.784 & 0.006 \\
\hline Age & & -0.062 & 0.022 & & -2.790 & 0.006 & & & & \\
\hline Constant & TOS-ASAL F3 & 12.137 & 0.424 & -0.190 & 28.628 & 0.000 & 0.190 & 0.036 & 6.033 & 0.015 \\
\hline Years of service & & -0.054 & 0.022 & & -2.456 & 0.015 & & & & \\
\hline Constant & TOS-ASAL F4 & 9.832 & 0.732 & -0.227 & 13.441 & 0.000 & 0.227 & 0.051 & 8.718 & 0.004 \\
\hline Age & & -0.051 & 0.017 & & -2.953 & 0.004 & & & & \\
\hline Constant & TOS-ASAL F4 & 8.332 & 0.328 & -0.163 & 25.378 & 0.000 & 0.163 & 0.026 & 4.376 & 0.038 \\
\hline Years of service & & -0.035 & 0.017 & & -2.092 & 0.038 & & & & \\
\hline Constant & TOS-ASAL total & 47.648 & 1.784 & -0.334 & 26.707 & 0.000 & 0.334 & 0.111 & 20.181 & 0.000 \\
\hline Age & & -0.188 & 0.042 & & -4.492 & 0.000 & & & & \\
\hline Constant & TOS-ASAL total & 43.048 & 0.788 & -0.340 & 54.596 & 0.000 & 0.340 & 0.116 & 21.071 & 0.000 \\
\hline Years of service & & -0.187 & 0.041 & & -4.590 & 0.000 & & & & \\
\hline Constant & TMS internal & 24.496 & 2.835 & 0.155 & 7.583 & 0.000 & 0.155 & 0.024 & 3.978 & 0.048 \\
\hline TOS-ASAL F1 & & 0.387 & 0.194 & & 1.994 & 0.048 & & & & \\
\hline Constant & TMS internal & 32.974 & 2.738 & -0.172 & 12.044 & 0.000 & 0.172 & 0.030 & 4.910 & 0.028 \\
\hline TOS-ASAL F3 & & -0.530 & 0.239 & & -2.216 & 0.028 & & & & \\
\hline Constant & TMS external & 7.667 & 1.712 & 0.316 & 4.477 & 0.000 & 0.316 & 0.100 & 17.872 & 0.000 \\
\hline TOS-ASAL F1 & & 0.496 & 0.117 & & 4.228 & 0.000 & & & & \\
\hline Constant & TMS external & 11.882 & 1.450 & 0.159 & 8.192 & 0.000 & 0.159 & 0.025 & 4.190 & 0.042 \\
\hline TOS-ASAL F2 & & 0.438 & 0.214 & & 2.047 & 0.042 & & & & \\
\hline Constant & TMS external & 20.638 & 1.683 & -0.271 & 12.264 & 0.000 & 0.271 & 0.073 & 12.735 & 0.000 \\
\hline TOS-ASAL F3 & & -0.525 & 0.147 & & -3.569 & 0.000 & & & & \\
\hline Constant & TMS external & 18.811 & 1.536 & -0.209 & 12.245 & 0.000 & 0.209 & 0.044 & 7.336 & 0.002 \\
\hline TOS-ASAL F4 & & -0.525 & 0.194 & & -2.709 & 0.007 & & & & \\
\hline Constant & TMS total & 29.163 & 4.083 & 0.241 & 7.142 & 0.000 & 0.241 & 0.058 & 9.969 & 0.002 \\
\hline TOS-ASAL F1 & & 0.883 & 0.280 & & 3.157 & 0.002 & & & & \\
\hline Constant & TMS total & 34.510 & 3.374 & 0.173 & 10.230 & 0.000 & 0.173 & 0.030 & 4.964 & 0.027 \\
\hline TOS-ASAL F2 & & 1.109 & 0.498 & & 12.228 & 0.027 & & & & \\
\hline
\end{tabular}

\section{DISCUSSION AND CONCLUSION}

According to the results of the analysis, it was determined that the opinions of science teachers about student achievement and learning were positive in the total scale and sub-dimension scores, and their teaching motivation was just above the average in the total scale and sub-dimension scores. These results are in accordance with similar studies (Abu Radwan, 2019; Beck et al., 2000; Levitt, 2002; Liu, 2003; Turan, 2019). There are studies on motivation and its positive effects on learning (Fernet et al., 2012; Glynn et al., 2005; Karadağ et al., 2010; Martin, 2013; Öztürk and Dündar, 2003; Randler et al., 2012; Vallerand et al., 1997). A study by Akioka and Gimore (2013) on students revealed that homework intervention may have had a positive effect on motivation of students. Argon and Ertürk (2013) concluded that primary school teachers' intrinsic motivation perceptions were high. A study conducted by Kaya et al. (2013) on the motivation levels of teachers working in the Adalar and Güngören districts of Istanbul concluded that the level of teachers' intrinsic motivation in both regions was higher than the extrinsic motivation factors. A study conducted by Yalçın and Korkmaz (2013) with preschool teachers concluded that preschool teachers did not have many problems relating to the teaching profession and they generally had high motivation. There have been studies showing that teacher beliefs do not necessarily influence classroom practice due to several factors (Hancock and Gallard, 2004; Mellado, 1998).

Results for the second question of the study "Do Secondary Science Teachers' Opinions on Student Success and Learning and their teaching motivation show a significant difference according to gender?" The difference between the groups in terms of TOS-ASALF4 was in favor of male science teachers, TMS internal in favor of female science teachers, and TMS total in favor of female science teachers. However, there was no difference according to gender in terms of other variables. There is a study which found significant differences between teachers' intent to implement and their gender, and according to the results, female teachers are more likely to implement the targeted behavior than male teachers for both critical voice 
and student negotiation (Beck et al., 2000). The findings of another study indicated that women were more likely to intend to implement reforms strands than men (Haney et al., 2002).

An independent group t-test was conducted to determine secondary school science teachers' opinions on student achievement and learning and their teaching motivation. It shows a significant difference according to their educational level. The results of the analysis showed that there was a significant difference in favor of science teachers who have a bachelor's degree between the groups in terms of the TOSASAL F1 sub-dimension. This result is striking. As the level of education increases, teachers are expected to have more positive opinions. Our results showed the opposite and no difference in other dimensions. This could be the subject of research in future studies. A study found that teachers possess positive attitudes about teaching for personal relevance, but teachers with bachelor's and master's degrees had a more positive attitude toward teaching for personal relevance than teachers with doctoral degrees (Beck et al., 2000).

Pearson correlational analysis was conducted regarding the fourth study question "What is the relationship between secondary school science teachers' views on student achievement and learning, their teaching motivation levels, and the teachers' age and years of service?" According to the results, there was a low-level statistically significant relationship between the TOS-ASALF2 sub-dimension and age and years of service. There was a low-level negative relationship between the sub-dimension TOS-ASALF3 and age and years of service. There was a low negative meaningful relationship between the sub-dimension TOS-ASAL F4 and age and years of service. Interestingly, there was a mediumlevel negative relationship between sub-dimension TOSASAL total and age and years of service. These results suggest that as the age and teachers' years of service increase, their views on student achievement and learning becomes more negative.

There is a low-level positive meaningful relationship between the sub-dimension TOS-ASAL F1 and TMS internal and TMS in terms of the Teachers' Opinions Scale about Student Achievement and Learning and Teaching Motivation Scale. It has been determined that there is a medium-level positive relationship between the TOS-ASAL F1 and TMS external.

There was a low-level positive meaningful relationship between the sub-dimension TOS-ASALF2 and TMS external and TMS. It was noted that there is a low-level negative relationship between the sub-dimension TOS-ASAL F3 and TMS internal, TMS external, and TMS total. It should be taken into account that there is a relationship between teachers' views on student learning and achievement for teaching motivation. A study by İçöz (2012) examining the relationship between secondary school student attitudes toward a chemistry course, motivation, and self-efficacy beliefs concludes that there are high correlations between students' attitudes toward chemistry, motivation, and self-efficacy beliefs.
In our study, these teachers' views on their students' achievement and learning were less predictive of teaching motivation. Another study found that attitude toward the teaching profession was a significant predictor of both intrinsic and extrinsic motivations (Ayık and Ataş, 2014).

According to the results of the study, it is recommended to organize well-planned in-service trainings to increase the teaching motivation. However, further in-depth research should be conducted to understand the relationship among teacher beliefs, practice, and school context. Similarly, as teachers' opinions about students' success and learning become more negative as get older, other teacher populations would be another fruitful area for further investigation. Finally, when the results are examined, it is possible to say that classroom observations reflect what is actually done in classroom setting.

\section{REFERENCES}

Abu Radwan, A. (2019). Changes in prospective teachers' beliefs about foreign language learning in a teacher training program. Sultan Qaboos Universtiy Journal of Art and Social Sciences, 10(2), 37-48.

Akioka, E., \& Gilmore, L. (2013). An intervention to improve motivation for homework. Australian Journal of Guidance and Counselling, 23(1), 34-48.

Alam, M.T., \& Farid, S. (2011). Factors affecting teachers motivation. International Journal of Business and Social Science, 2(1), 298-304.

Anderson, R.D., \& Mitchener, C.P. (1994). Research on science teacher education. In: Gabel, D.L., (Ed.), Handbook of Research on Teaching and Learning. United States: Macmillan and National Science Teachers Association. pp. 3-44.

Argon, T., \& Ertürk, R. (2013). İlköğretim okulu öğretmenlerinin içsel motivasyonları ve örgütsel kimliğe yönelik algıları. Kuram ve Uygulamada Eğitim Yönetimi [Educational Administration in Theory and Practice], 19(2), 159-179.

Ayık, A., \& Ataş, Ö. (2014). The relationship between pre-service teachers' attitudes towards the teaching profession and their motivation to teach. Journal of Educational Sciences Research International E-Journal, 4(1), 26-43.

Bardak, Ş., \& Karamustafaoğlu, O. (2016). Investigation about using strategies, methods and techniques of science teachers based on pedagogical content knowledge. Amasya Education Journal, 5(2), 567-605.

Beck, J., Czerniak, C.M., \& Lumpe, A.T. (2000). An exploratory study of teachers' belief regarding the implementation of constructivism in their classrooms. Journal of Science Teacher Education, 11(4), 323-343.

Bloom, B.S. (1971). Individual Differences in School Achievement: A Vanishing Point. A Monograph. AERA-pdk Award Lecture Annual Meeting American Educational. New York: Research Association.

Borg, M. (2001). Teachers' beliefs. ELT Journal, 55(2), 186-188.

Borko, H., \& Putnam, R.T. (1996). Learning to teach. In: Berliner, D.C., \& Calfee, R.C., (Eds.), Handbook of of Educational Psychology. United States: Prentice Hall International. pp. 673-708.

Bullough, R.V. Jr. (1989). First-Year Teacher: A Case Study. United States: Teachers College Press.

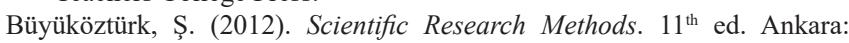
Pegem A Academy.

Büyüköztürk, Ş. (2018). Sosyal Bilimler İçin Veri Analizi el Kitabı [Handbook of Data Analysis for Social Sciences]. Ankara: Pegem A Academy.

Chai, C.S., \& Khine, M.S. (2008). Assessing the epistemological and pedagogical beliefs among pre-service teachers in Singapore. In: Khine, M.S., (Ed.), Knowing, Knowledge, and Beliefs: Epistemological Studies Across Diverse Cultures. Germany: Springer. pp. 287-299.

Clark, C., \& Peterson, P. (1986). Teachers' thought processes. In: Wittrock, M., (Ed.), Handbook of Research on Teaching. $3^{\text {rd }}$ ed. United States: Macmillan. pp. 255-296. 
Demir, M.K. (2013). İlköğretim bölümü öğretmen adaylarının epistemolojik inançlarının incelenmesi. Uludağ Üniversitesi Eğitim Fakültesi Dergisi [Journal of Uludağ University Education Faculty], 25(2), 343-358.

Demir, S., \& Akınoğlu, O. (2010). Epistemological beliefs in teaching and learning processes. Marmara University Atatürk Education Faculty Journal of Educational Sciences, 32(32), 75-93.

Dewey, J. (1938). Experience and Education. United States: Macmillan Company.

Dörnyei, Z., \& Ushioda, E. (2011). Teaching and Researching Motivation. $2^{\text {nd }}$ ed. United Kingdom: Pearson.

Ediger, M. (2000). Philosophy perspectives in teaching social studies. Journal of Instructional Psychology, 27(2), 112.

Etchberger, M.L., \& Shaw, K.L. (1992). Teacher change as a progression of transitional image: A chronology of a developing constructivist teacher. School Science and Mathematics, 92, 411-417.

Fernet, C., Guay, F., Senecal, C., \& Austin, S. (2012). Predicting individual changes in teacher burnout: The role of perceived school environment and motivational factors. Teaching and Teacher Education, 28, 514-525.

Fives, H., \& Buehl, M.M. (2012). Spring cleaning for the "messy" construct of teachers' beliefs: What are they? Which have been examined? What can they tell us? In: Harris, K.R., Graham, S., \& Urdan, T.C., (Eds.), APA Educational Psychology Handbook, Individual Differences and Cultural and Contextual Factor. Vol. 2. United States: American Psychological Association. pp. 471-499.

Gales, M.J., \& Yan, W. (2001). Relationship between Constructivist Teacher Beliefs and Instructional Practices to Students' Mathematical Achievement: Evidence from TIMMS. Seattle, WA: The Annual Meeting of the American Educational Research Association.

Gallagher, J.J. (1991). Prospective and practicing secondary school science teachers' knowledge and beliefs about the philosophy of science. Science Education, 75, 121-133.

Geertz, C. (1973). The Interpretation of Cultures. United States: Basic Books.

Glynn, S.M, Aultman, L.P., \& Owens, A.M. (2005). Motivation to learn in general education programs. The Journal of General Education, 54(2), 150-170.

Gök, B., \& Kabasakal, K.A. (2019). Analysing prospective teachers' selfefficacy belief, teaching motivation and attitutes towards teaching from several variables. Pegem Eğitim ve Öğretim Dergisi [Pegem Education and Training Magazine], 9(4), 1081-112.

Güzel Candan, D., \& Evin Gencel, İ. (2015). Adaptation of the motivation to teach scale into Turkish. Mehmet Akif Ersoy Üniversitesi Eğitim Fakültesi Dergisi [Mehmet Akif Ersoy University Journal of Education Faculty], 36, 72-89.

Hancock, E.S., \& Gallard, A.J. (2004). Preservice science teachers' beliefs about teaching and learning: The influence of K-12 field experiences. Journal of Science Teacher Education, 15(4), 281-291.

Haney, J.J., Lumpe, A.T., Czernaik, C.M., \& Egan, V. (2002). From beliefs to actions: The beliefs and actions of teachers implementing change. Journal of Science Teacher Education, 13(3), 171-187.

Hashweh, M.Z. (1991). Palestinian Science Teachers' Epistemological Beliefs: A Search for the Constructivist Teacher. Palm Springs, CA: Paper Presented at the Sixth International IOSTE Symposium on World Trends in Science and Technology Education.

Hashweh, M.Z. (1996). Effects of science teachers' epistomological beliefs in teaching. Journal of Research in Science Teaching, 33(1), 47-63.

Hodson, D. (1985). Philosophy of science, science and science education. Studies in Science Education, 12, 25-57.

İçöz, Ö.F. (2012). The Relationship among Secondary School Students' Attitudes, Motivation and Self-Efficacy Beliefs Toward Chemistry Lessons, Unpublished Master's Thesis. Turkey: Middle East Technical University, The Graduate School of Natural and Applied Sciences.

Johnson, M. (2012). Bilingual degree teachers' beliefs: A case study in a tertiary setting. Puls, 35, 49-74.

Karadağ, E., Baloğlu, N., \& Küçük, E. (2010). The effects of the principa supervision' perception to work motivation of teachers: A study of pathy analysis. Türk Eğitim Bilimleri Dergisi [Turkish Journal of Educational Sciences], 8(2), 417-437.

Karasar, N. (2014). Scientific Research Method. $27^{\text {th }}$ ed. Ankara: Nobel Academic Publishing.
Kauffman, D.F., Yılmaz Soylu, M., \& Duke, B. (2011). Validation of the motivation to teach scale. Hacettepe University Journal of Education Faculty, 40, 279-290.

Kaya, F.Ş., Yıldız, B., \& Yıldız, H. (2013). An evaluation of the motivation levels of primary school teachers in terms of Herzberg's two-factor theory. Journal of Academic Perspective, 39, 1-18.

Kaya, Z. (2001). Psychological foundations of education. In: Demirel, Ö., \& Kaya, Z., (Eds.), Introduction to the Teacher Profession. Ankara: Pegem Publishing. pp. 199-218.

Kırkıç, K.A., Aydın, E., \& Yahşi, Ö. (2020). Teachers' opinions scale about students' achievement and learning (TOS-ASAL). IZU Journal of Education, 2(3), 137-154.

King, B.B. (1991). Beginning teachers' knowledge of and attitudes toward history and philosophy of science. Science Education, 75, 135-141.

Kuzborska, I. (2011). Links between teachers' beliefs and practices and research on reading. Reading in a Foreign Language, 23(1), 102-128.

Levitt, K.E. (2002). An analysis of elementary teachers' beliefs regarding the teaching and learning of science. Science Education, 86(1), 1-22.

Lieberman, A. (1992). The meaning of scholarly activity and the building of community. Educational Researcher, 22, 5-12.

Lin, Y.G., McKeachie, W.J., \& Kim, Y.C. (2003). College student intrinsic and/or extrinsic motivation and learning. Learning and Indvidual Differences, 13(3), 251-258

Liu, M. (2003). Teachers' beliefs about issues in the implementation of a student-centered learning environment. Educational Technology Research and Development, 1(2), 57-76.

Love, A. (2002). The Relationship Between Teachers' Beliefs and Student Achievement in Two Primarily African American Urban Elementary Schools. New Orleans, LA: The Annual Meeting of the American Educational Research Association.

Luft, J.A., \& Roehrig, G.H. (2007). Capturing sicence teachers' epistemological beliefs: The development of the teacher beliefs interview. Electronic Journal of Science Education, 11(2), 38-63.

Mansour, N. (2009). Science teachers' beliefs and practices: İssues, implications and research agenda. International Journal of Environmental and Science Education, 4(1), 25-48.

Martin, A.J. (2013). Improving the achievement, motivation, and engagement of students with ADHD: The role of personal best goals and other growth-based approaches. Australian Journal of Guidance and Counselling, 23(1), 143-155.

Mellado, V. (1998). The classroom practice of preservice teachers and their conceptions of teaching and learning science. Science Teacher Education, 82, 197-214.

Muijs, D., \& Reynolds, D. (2002). Teachers' beliefs and behaviors: What really matters? The Journal of Classroom Interaction, 37(2), 3-15.

Nadeau, R., \& Desautels, J. (1984). Epistemology and the Teaching of Science. United Kingdom: Science Council of Canada.

Öztürk, Z., \& Dündar, H. (2003). Organizational motivation and factors motivating public employees. Journal of Economic and Administrative Sciences, 4(2), 57-67.

Pajares, M.F. (1992). Teachers' beliefs and educational research: Cleaning up a messy construct. Review of Educational Research, 62(3), 307-332.

Prawat, R.S. (1992). Teachers' beliefs about teaching and learning: A constructivist perspective. American Journal of Education, 100, 354-395.

Randler, C., Hummel, E., \& Wüst-Ackermann, P. (2012). The influence of perceived disgust on students' motivation and achievement. International Journal of Science Education, 35(17), 2839-2856.

Rashidi, N., \& Mughadam, M. (2014). The Effect of teachers' beliefs and sense of self-efficacy on Iranian EFL learners' satisfaction and academic achievement. The Electronic Journal for English as a Second Language, $18(2), 1-23$.

Skott, J. (2015). The promises, problems, and prospects of research on teachers'beliefs. Science teacher attitudes and beliefs. In: Fives, H., \& Gill, M.G., (Eds.), International Handbook of Research on Teeachers' Beliefs. United Kingdom: Routledge. pp. 13-30.

Tabachnick, B.G., \& Fidell, L.S. (2013). Using Multivariate Statistics. United Kingdom: Pearson.

Trumball, D. (1991). What's a Teacher Know: What is a Teacher to be. Paper Presented at the Annual Meeting of the National Association for 
Research in Science Teaching, Lake Geneva, WI.

Turan, M.B. (2019). The relationship between university students' epistemological beliefs and teaching/learning conceptions. International Journal of Progressive Education, 15(1), 184-194.

Vallerand, R.J., Fortier, M.S., \& Guay, F. (1997). Self-determination and persistence in a real life setting: Toward a motivational model of high school dropout. Journal of Personality and Social Psychology, 72(5), 1161-1176. von Glasersfeld, E. (1987). The Construction of Knowledge: Contributions to Conceptual Semantics. United States: Intersystems Publications.

Yalçın, H., \& Korkmaz, M.E. (2013). Preschool teachers' conditions of motivation. International Journal of Social Research, 6(26), 602-609.

Yildıran, G. (2006). Multicultural Applications of Mastery Learning: Our Thoughts, Our Deeds and Our Hopes for Education. Turkey: Boğaziçi University. 